
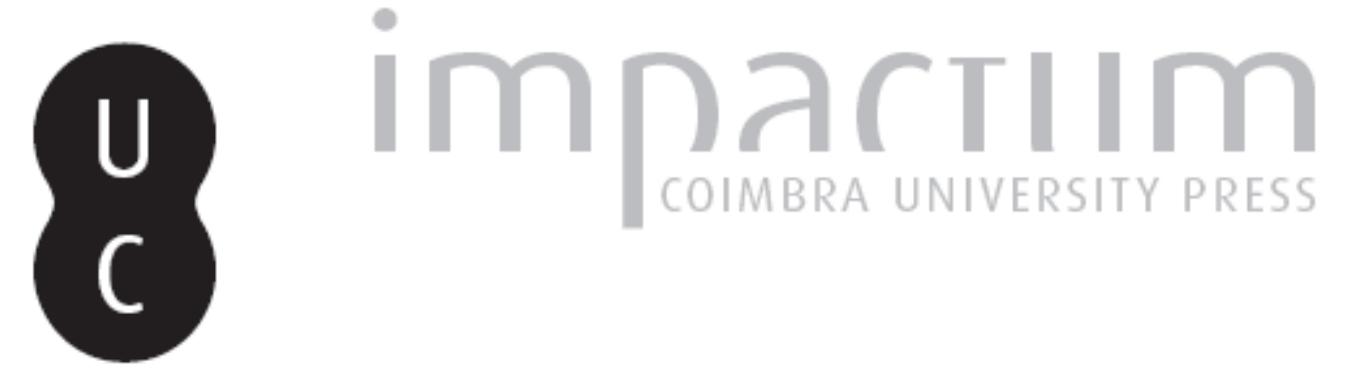

\title{
Expor e comunicar em Historia e em Arqueologia
}

\section{Autor(es): D'Encarnação, José}
Publicado por: Instituto de História Económica e Social; Imprensa da Universidade de Coimbra
URL persistente:
URI:http://hdl.handle.net/10316.2/44512
DOI:
DOI:https://doi.org/10.14195/0870-4147_37_20

Accessed : $\quad$ 26-Apr-2023 16:22:19

A navegação consulta e descarregamento dos títulos inseridos nas Bibliotecas Digitais UC Digitalis, UC Pombalina e UC Impactum, pressupõem a aceitação plena e sem reservas dos Termos e Condições de Uso destas Bibliotecas Digitais, disponíveis em https://digitalis.uc.pt/pt-pt/termos.

Conforme exposto nos referidos Termos e Condições de Uso, o descarregamento de títulos de acesso restrito requer uma licença válida de autorização devendo o utilizador aceder ao(s) documento(s) a partir de um endereço de IP da instituição detentora da supramencionada licença.

Ao utilizador é apenas permitido o descarregamento para uso pessoal, pelo que o emprego do(s) título(s) descarregado(s) para outro fim, designadamente comercial, carece de autorização do respetivo autor ou editor da obra.

Na medida em que todas as obras da UC Digitalis se encontram protegidas pelo Código do Direito de Autor e Direitos Conexos e demais legislação aplicável, toda a cópia, parcial ou total, deste documento, nos casos em que é legalmente admitida, deverá conter ou fazer-se acompanhar por este aviso.

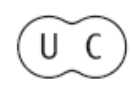




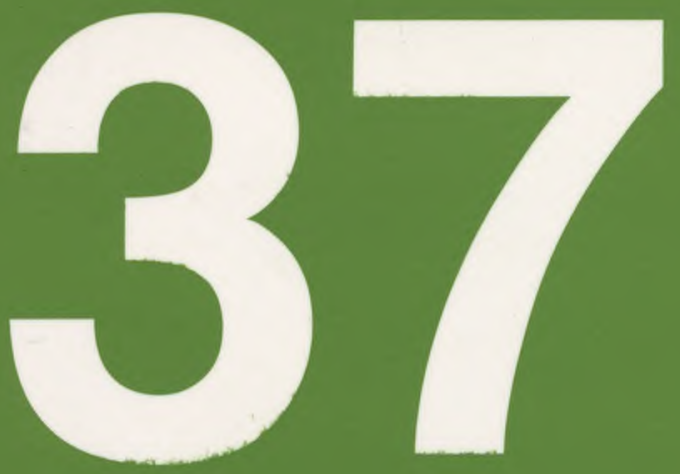

Revista Portuguesa de História

Faculdade de Letras da Universidade de Coimbra Instituto de Historia Econónica e Samial

Coimbra 05 


\section{Expor e comunicar em Historia e em Arqueologia}

A publicação do catálogo da exposição permanente do Museu do Rabaçal suscita, pela suas características, um conjunto de questões que vão desde aspectos museológicos (critérios de selecção e de exposição das peças) aos objectivos e métodos da comunicação científica.

Num momento em que a História e a Arqueologia fazem parte intrínseca do quotidiano, importa reflectir, partindo do exemplo concreto da villa romana ROTEIRO do Rabaçal (Penela), sobre a eficácia real dos métodos e dos conteúdos.

Definitivamente retiradas - por própria e alheia vontade - das torres de marfim de privilegiado acesso, a História e a Arqueologia integram o quotidiano de todo o cidadão.

Outros, muito melhor que eu, alicerçados em eloquentes teorias 
- que não leio mas decerto perfilho a partir do olhar atento -, saberão explicar como essa atitude generalizada deriva, por um lado, da chamada globalização e, por outro, do ilimitado desnudar que, aparentemente, não deixa margem para as delícias do entrever, do enigma aliciante e sedutor...

Uniformizámos os pêssegos, calibrámos os tomates, vestimo-nos das mesmas marcas - e sentimos, por isso, a necessidade de distinção. Assim, embora se apregoe que se repete, a História, designadamente a História local e regional, oferece a resposta certa, no momento mais oportuno, ingredientes de sobra para uma diferenciação consciente!

A Arqueologia, por seu tumo, alimentava deslumbramentos muitos, depois das sagas napoleónicas no Egipto, das incursões magníficas de americanos e de ingleses e de franceses também em terras do Médio Oriente, berço da Humanidade, tesouros de muito espantar! E Pompeios?!... E os Etruscos?!...

«Ciência auxiliar da História» chamavam-lhe displicentemente. Cedo, porém, mercê de uma metodologia própria; graças ao progressivo aperfeiçoamento das técnicas de escavação; devido à crescente utilização de rigorosos métodos laboratoriais de análise - a Arqueologia assume-se, hoje, sem objecções, como uma ciência social e humana, sim, mas com larguíssima vertente das ciências ditas exactas. O que veio subitamente despertar sempre renovados interesses. Desta sorte, expor e comunicar em História e em Arqueologia representam, neste dealbar do século XXI, tarefas imprescindíveis.

Atenhamo-nos ao significado mais concreto do verbo expor: mostrar, saltar da torre de marfim. E a Museologia veio, de imediato, em socorro da foragida e, no diálogo, lhe deu abrigo seguro. E o marketing. E a publicidade. Num bem caldeado entrelaçar de intenções.

Entretanto, também as técnicas da comunicação se adaptaram rapidamente. Consciencializou-se - finalmente! - que comunicar implica sintonia entre emissor e receptor (há, seguramente inúmeras teorias a este propósito...). Sintonia preexistente ou sintonia que urge criar, sob pena de tudo se perder no espaço etéreo, sem proveito para ninguém, nem para o próprio emissor, por mais que se tente convencer: se não tiver eco do que fez, sentirá bem desconfortável vazio, de bem funestas consequências.

Não constitui minha intenção, é óbvio, embrenhar-me nas técnicas da exposição - que para isso há cursos específicos, como o Mestrado em Museologia e Património Cultural da Faculdade de Letras da Universidade de Coimbra. Não dissertarei sobre a melhor forma de comunicar - que, depois do livro Como Falar com Jornalistas sem Ficar à Beira de um Ataque de Nervos 
(Guia para Investigadores e Profissionais de Comunicação) (Gradiva, Lisboa, Abril de 2001), da autoria de dois jornalistas do Público, António Granado e José Vítor Malheiros, em boa hora patrocinado pelo mui esclarecido Ministério da Ciência e da Tecnologia de Mariano Gago, difícil será algo acrescentar.

Seja-me permitido, porém, que, reunindo a experiência profissional de docente em Museologia e de Comunicação Social, use um exemplo concreto, na tentativa de melhor consciencializarmos as questões enunciadas. «Consciencializar», «tomar consciente» e «objectivos» tomaram-se-me, aliás - e que o leitor me perdoe! - palavras quase obsessivas no magistério, tamanhas têm sido as lacunas que, nesses domínios, venho encontrando.

Primeiro, porque, na verdade, a Epigrafia, disciplina que também lecciono, vive precisamente desse «colocar de questões» - e, se as não colocamos, arriscamo-nos a pouco compreender. Depois, porque a não-concretização prévia dos objectivos a alcançar distorce, amiúde, a visão do caminho a percorrer.

Escolhi, para o efeito, um livro aparentemente de temática arqueológica mas que é, no fundo, multidisciplinar, pois nele se imbricam os dados arqueológicos, as artes e a Etnografia... Dir-se-ia, até, que a Arqueologia se assomou, aqui, em jeito de mero pretexto para se traçar o retrato singular duma aldeia, que - por acaso? - tem lindas ruínas romanas, uma história rica e uma paisagem de invejar.

De aparência modesta, formato despretensioso, 72 páginas, capa de cartolina mole - denuncia, logo à partida, a exiguidade dos meios financeiros de que, afinal, se dispôs para a edição. Mas o grafismo foi preciosamente cuidado; o desenho da capa, deveras significativo; a pintura a óleo, de Fernando Namora (1935), a cores, reproduzida, em pequenas dimensões, a meio da contracapa, um toque de requinte a apreciar.

Chama-se ROTEIRO. Junto ao desenho, de mui inteligente concepção, temos, como que em legenda, os dizeres, desenhados também, duas linhas de letra cursiva, Rabaçal Aldeia Cultural; ao fundo, PENELA. PORTUGAL.

«Roteiro». Roteiro de quê? Da aldeia?

E porquê «Portugal»? Será que esta edição, em língua portuguesa, se destina também ao mercado turístico?

A ficha técnica vem na primeira badana: foram autores Miguel Pessoa, Lino Rodrigo e Sandra Steinert Santos; o design é de José Luís Madeira; as fotos, de António Pinto e do saudoso Delfim Ferreira; a edição, da Câmara Municipal de Penela, apoiada pelo Centro Rural de Sicó; a tiragem, de «2000 exemplares - Português», referência que dá a entender que, além desta versão, datada de 2001, outras existem ou virão a existir, noutros idiomas. E desta sorte se compreende a referida inclusão da palavra PORTUGAL. 
O rosto institucionaliza o Roteiro, pois que, aí, é o brasão da Câmara Municipal de Penela que aparece e, na página 3, o respectivo presidente, Femando dos Santos Antunes, data de 5 de Maio de 2001 as palavras de ocasião que proferiu e que importava serem escritas, começando pela afirmação «Está pronto o edifício!».

Descortina-se, assim, o significado cabal: a obra é o roteiro desse edifício, o Espaço-Museu da Villa Romana do Rabaçal. Aliás, o presidente explicita-o claramente:

«Este Roteiro significa caminhada, amizade, solidariedade e juventude».

Temos, pois, um espaço expositivo, criado de raiz, a servir de apoio à referida villa romana. Ali se mostrarão os objectos mais significativos; se explanará o significado dos vestígios estruturais encontrados; em suma, se acolherá o visitante e lhe serviremos de guia. Um guia a iluminar caminhadas - pensa-se.

Difere um «roteiro» de um «catálogo». O catálogo pressupõe estudo circunstanciado das peças expostas, precedido normalmente de uma ou várias panorâmicas de síntese, destinadas a fornecer o devido enquadramento histórico-cultural. O roteiro é mais simples, acompanhante do que se vê, sem alardes nem discursos arredios. Tanto num como noutro, a composição gráfica tem de ser clara, de leitura fácil, de quase instantânea individualização. Só que o roteiro é para 1 er todo no momento em que se passa defronte da peça ou se percorre um espaço; o catálogo terá uma parte destacada, de leitura imediata, e um comentário de pormenor, mais técnico ou especializado, que só se lê no momento se se quiser de imediato aprofundar o conhecimento sobre o assunto; de um modo geral, porém, essa parte fica para 1er em casa, sobretudo em tempo de consulta específica.

Antes, portanto, de iniciarmos a leitura deste Roteiro - e, sobretudo, após o prólogo do Sr. Presidente - ficamos convictos de que vamos ser guiados pelo Espaço-Museu da Villa Romana do Rabaçal: que peças, que estruturas, que importância. De resto, necessitaremos de saber, em primeiro lugar, o que é um espaço-museu: um centro interpretativo? Um museu no sentido próprio do termo, criado de raiz, assim como o Museu Monográfico de Conímbriga, a contar-nos, pelos materiais expostos, o modo de vida dos romanos que no Rabaçal viveram? Um museu a conviver com as ruínas ou um museu que inclui as ruínas como um dos seus pólos?

As páginas 5 e 6, com o título «Sumário» elucidam-nos. Estaremos perante uma exposição em três núcleos:

- o museu, com dois pisos, o primeiro destinado a exposições temporárias e à apresentação de alguns temas que poderíamos apelidar de 'memória deste sítio', e o segundo sobre a villa romana;

- a villa romana e o seu edifício de apoio;

- o núcleo da vista panorâmica de Chanca, que é, no fundo, o miradouro com um mosaico panorâmico. 
No final da pág. 6 se indica, em nota, que o trabalho foi elaborado em 1999, no âmbito do Plano Nacional de Trabalhos Arqueológicos e com o apoio de diversas entidades.

A temática do rés-do-chão está dividida em nove pontos, que se suporia, em princípio, serem elementos do mesmo conjunto (em extensão e características), mas que, lendo bem, intelectualmente nos perturbam. Sendo o lugar das exposições temporárias, compreende-se que se refira a pintura, exposta, de Manuel Filipe e os mosaicos contemporâneos. Contudo, «5. Miliário dos Tamazinhos» é, seguramente, uma peça arqueológica, enquanto «6. Tempos de trabalho e pausa», «7. Cronologia», «8. Necrópole do século XVI» pertencem, na realidade, a esquemas mentais mui diversificados e não vemos bem como se entrecharão. De resto, se o logotipo da villa, num dos cantos superiores de cada página é graficamente sugestivo, assim como o é o simpático golfinho reproduzido por cima do número de página, já se não compreende bem o que, na pág. 5, andam aqueles três homens nus a fazer, junto ou em cima duma árvore: a colher o quê? Que frutos? $\mathrm{E}$ donde é que vem essa imagem? Talvez o texto, mais adiante, o elucide. E o que quererá dizer «Necrópole do século XVI»?

Curioso é, porém, verificar que se abre o sumário com uma citação de Ernesto Veiga de Oliveira, etnólogo, a reclamar atenção sobre o continuum que é a civilização de um povo; se explica que a exposição «é composta por 23 painéis» que formam «um percurso informativo, distribuído pelos três núcleos»; e, considerando a intenção de fazer a avaliação do trabalho, incita-se o visitante: «Deixe-nos, se assim o desejar, algumas linhas sobre a escolha e o conteúdo dos temas tratados».

Assalta-nos, por isso, uma dúvida: não serão essas duas páginas a transcrição pura e simples de um folheto distribuído ao visitante e não será a página 72 , a última do livro, em branco e com o título «Notas», o lugar para deixar essa opinião? Se o é, como se faz? Prantar-se-ão aí as notas e arranca-se a página do livro?

Começa na pág. 7 a explanação dos conteúdos dos números 1 a 9 do rés-do-chão.

Bonita a saudação, o convite a voltar sempre e a apresentação sucinta dos núcleos, uma apresentação em que se preconiza, desde logo, a contemplação das ruínas integradas na paisagem que as viu nascer:

«Fique e encante-se com o silêncio desta paisagem cársica, seca, cinza, sinuosa e nua, talhada por muitos, durante séculos».

De facto, discorre-se largamente, em letra miudinha e com ilustrações, sobre o conteúdo de cada um dos nove pontos enunciados. Assim, a pretexto dos dois mosaicos contemporâneos, tecem-se considerações amplas sobre os vários artistas que o têm utilizado e traça-se uma panorâmica sobre a arte do mosaico desde os Romanos aos nossos dias: «No futuro, que nos reservará esta expressão artística?» (p. 13). 
O miliário ( $\mathrm{n}^{\circ}$ 5), do tempo do imperador Décio, do qual se dá leitura interpretada e tradução, da autoria de Vasco Mantas (que trata deste monumento, por exemplo, nas p. 308-312 do vol. I da sua dissertação de doutoramento, inédita, A Rede Vidria Romana da Faixa Atlântica entre Lisboa e Braga, Coimbra, 1996), constitui pretexto para se falar das vias de comunicação aí, desde a Proto-História até à actualidade. Diz-se, nomeadamente, que o miliário, dedicado ao «enérgico imperador» Décio, «autor de rigorosas perseguições contra os cristãos», «honra, ainda, os seus dois filhos Herénio e Hostiliano» (p. 14). Anotemos que não será bem essa a interpretação: não se trata, de facto, de uma coluna honorífica, mas sim de um miliário com funções informativas claramente patentes, pois indica, no final, que dali até Conímbriga oito milhas se devem contar. A iniciativa deve-se a dois Césares, Herénio e Hostiliano, cujos nomes se encontram em nominativo (como sujeitos da acção) e foi feita quando seu pai detinha o $3^{\circ}$ poder tribunicio, ou seja, em 250 d. C., o ano em que ambos foram nomeados Césares. $\mathrm{O}$ nome do imperador está em ablativo (e não em dativo, como se transcreve), a indicar circunstância de tempo.

Os autores aproveitam o ensejo para - em jeito de pausa onde até a língua gestual portuguesa tem presença!... - darem, em 22 línguas, a tradução da expressão «Todos os caminhos vão dar a Roma» (p. 16). Parecerá mero apontamento de passagem; não o é, porém, porque - sabê-lo-emos por minúscula anotação no quadro da pág. 19 - esse é o título do programa europeu em que o Rabaçal se integra!

No $n^{\circ} 6$ (p. 17), o tema é «tempos de trabalho e de pausa», ilustrado por duas fotos, cuja legenda vem na p. 56 (é preciso descobrir, pois o livrinho não tem índice): uma, de um grupo de crianças mascaradas pelo Carnaval, e a outro do trabalho de salmejar o cereal, no Rabaçal. «Salmejar» é termo tradicional, desusado já (e por isso não registado em todos os dicionários), que significa ajuntar o cereal que, depois de cortado, ficou pelo campo e que é preciso levar para a eira. Assim, Carnaval é «pausa»; o salmejar, trabalho. O texto, poético, encimado por excerto de poema de António Gedeão, começa assim:

«O tempo, que tem todo o tempo, marca o ritmo das horas, dos dias, das semanas, dos meses, dos séculos, dos milénios...

E é assim com todos e em todo o mundo. Mas é-o mais para os que, jardineiros da paisagem, desenvolvem o seu trabalho no alegrar dos agueiros, no levantamento dos muros, no plantio das terras, no varejar das azeitonas, na colecta das plantas etno-medicinais, no acompanhamento dos arcaicos cortiços e das colmeias»».

Esse, o trabalho; agora, a pausa:

«É preciso dar ouvidos ao repicar alegre dos sinos; ao toque do gaiteiro; ao rebentar do foguete; à dança; ao crepitar da fogueira dos Santos; à literatura oral mil vezes repetida e sempre nova do Melo e Gerumelo». 
Compreende-se, ao 1er o parágrafo final, que se está a preparar o leitor e o visitante para ver com outro olhar as «fotografias etnográficas» e os livros - da autoria de etnógrafos consagrados - «convite para uma reflexão sobre o trabalho e a festa, sobre as terras e as gentes do Rabaçal».

$\mathrm{O} \mathrm{n}^{\circ} 7$ (p. 18-19) é minucioso quadro cronológico, em que cada período é identificado por um objecto que o tipifica e onde se põem em paralelo acontecimentos no Rabaçal, em Roma e na Lusitânia, desde 250 a 1996 - para mostrar que, afinal, a aldeia sempre andou bem integrada no tempo e no espaço!

Técnicos do Laboratório de Paleodemografia e Paleopatologia do Departamento de Antropologia da Universidade de Coimbra fazem (p. 20-22) uma assaz curiosa síntese do estudo que levaram a efeito, em 1998 e 1999, sobre as ossadas provenientes da necrópole que, no século XVI, se instalou na villa romana. E «curiosa» constitui, de facto, o termo correcto, porque - além do aspecto sugestivo das imagens - se lograram diagnosticar patologias sofridas pelos indivíduos ali sepultados. Creio que seria querer ir longe de mais pretender saber-se «as eventuais relações de parentesco entre os indivíduos inumados nesta necrópole» (p. 22), mas... louve-se tal intenção!

Destina-se o $\mathrm{n}^{\circ} 9$ (p. 23-24) a dar conta doutra «memória»: a história do hospital de Nossa Senhora da Piedade, hoje transformado em «pousada», e da Casa do Passal, residência do pároco, tudo legados de um benemérito rabacelense, o Juiz Desembargador Lúcio Augusto Xavier de Lima, que suporíamos ser o senhor representado ao lado, em foto do desenho a carvão, identificado com o $\mathrm{n}^{\circ}$ 20. E é, como se explicita na tal p. 56, das legendas. Só que, no texto, se remete para a fig. 14: um osso exemplificativo da osteocondrite dissecante! De resto, a dar crédito ao texto dessa página, as crianças não são as que prazenteiramente se apresentam com fotografia ao lado, sob o $\mathrm{n}^{\circ} 18$, mas sim... o esqueleto feminino da pág. 20; e os participantes no Campo de Trabalho Internacional de 1989 ficaram reduzidos a... um crânio com sinais de stresse (fig. 13)!... E valerá a pena 1er os dois primeiros parágrafos dessa pág. 23:

«O Rabaçal, aldeia da Serra do Sicó, antiga Vila, detém hoje um palácio romano, riquíssimo, arrancado das entranhas das suas terras pregueiras [sic] onde a aveia não cresce senão moderadamente e as pastagens são rasteiras.

A arqueologia trouxe-o à luz e as crianças locais, suas primeiras destinatárias, viram e desenharam os vestígios, embeveceram-se e orgulharam-se, como é tão saudável acontecer na serra solitária».

As páginas 25 a 34 trazem textos de «acompanhamento» da exposição permanente: a pedra; o metal; a cerâmica; o vidro; o homem e a mulher; "villa romana: uma obra inacabada". E os Núcleos de Exposição (p. 35-53) são pretexto 
para interessantes peças literárias, de temática variada, desde a de índole meramente noticiosa à explicação técnica de tipo arqueológico.

As p. 54-55, sob o título «Mosaico panorâmico», apresentam-se em jeito de conclusão, pensar-se-ia, porque antecedem a lista das legendas das ilustrações e a extensa bibliografia temática que ocupa as pág. 57 a 71 ! No entanto, o texto começa assim:

«Está no Rabaçal, Aldeia Cultural!

Em mãos, tem agora este desenho. Olhe-o».

Explica-se o desenho; chama-se a atenção «para a Paisagem cársica que sobe do fértil vale até aos secos montes do Melo e Gerumelo»; e remata-se:

«Está no Rabaçal, aldeia cultural. Entre outros, o mosaico aqui é uma especificidade muito própria, por isso o privilegiámos nesta folha moldada pela caligrafia das crianças da Escola do primeiro Ciclo local».

Uma caligrafia bonita, de meninos muito certinhos, sobredotados, que até sabem o que é uma «paisagem cársica que sobe»!...

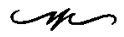

Tempo, pois, de concluir.

Este Roteiro tem subjacente a si, claramente, a ideia do «ecomuseu». Um sítio arqueológico, vestígio de remotas existências outras, não pode ser desgarrado do contexto. Quer daquele em que viveu, quer do que, hoje em dia, o envolve. E há que proporcionar ao visitante esta ampla visão de conjunto. Que um sítio nunca morre, altera-se. Por vontade dos homens e pela força dos elementos. E essa é leitura estimulante e viva.

No fundo, porém, esta letra miudinha, esta manta de retalhos, este repetir de ideias resultantes do facto - bem claro! - de que estamos perante uma colagem de textos das mais diversas características, porque (inclusive) saídos das mais diversas mãos, não ajudam a criar essa noção. Há bem bonitos nacos de prosa; há ilustrações magníficas (mas que nem sempre cumprem o papel de «ilustração») - contudo, a amálgama não saiu perfeita.

\section{E porquê?}

Por, em meu entender, não se ter pensado claramente nos objectivos a atingir! É preciso fazer um livro? - Faz-se! Importava, antes, reflectir sobre o como e o porquê. E será um livro só ou vários? De prestígio ou sem pretensões gráficas? Científico ou de divulgação?

Como está, o Roteiro cumpre simultaneamente todas estas funções, mas o leitor, mesmo que tenha paciência para esquadrinhar até final esses caracteres pequeninos, dificilmente disso se aperceberá. Pelo nosso lado, veríamos aqui, se articulada melhor, uma obra de prestígio, com duas partes distintas: reuniam-se 
na primeira textos de autor, sínteses cuidadas dos temas tratados (arqueologia, etnografia, geografia física e humana, antropologia, história...); constituía a segunda o guia da visita, em termos singelos e concisos.

Dir-se-á: «Fez-se o que se pôde, com os dinheiros disponíveis». Concordo. Fora outra a ambição, clarificados os objectivos, potenciado o aspecto gráfico, não teria a autarquia dificuldade em 'vender a ideia' a um ilustrado mecenas e em justificá-la plenamente junto dos seus munícipes eleitores. É que, senhores, está lá tudo! A roupagem é que não obedece às regras do marketing! 